\title{
PROBLEM-BASED ESP METHODS FOR TEACHING FUTURE AIR TRAFFIC CONTROLLERS TO CONDUCT RADIO EXCHANGE IN NON-ROUTINE SITUATIONS
}

\author{
Bogdana Bystrova (corresponding author), Liudmyla Nemlii, \\ Nataliya Pazyura, Oksana Vasiukovych \\ National Aviation University, Kyiv, Ukraine \\ danabystrova@gmail.com
}

\begin{abstract}
The research aimed to study and experimentally verify the efficiency of the use of problem-based methods in teaching future air traffic controllers to conduct radio exchange in non-routine situations. The professional readiness to conduct radio exchange is viewed as a complex of professional skills and knowledge (communicative, cognitive and functional) enhanced by motivation. The study involved 67 university students of a bachelor's degree programme majoring in "Aviation transport". Tests, observations and specially designed questionnaires were used to evaluate the use of problem-based methods (role-playing, simulation of specific situations, problem-solving, case studies) in ESP study. The conclusion was made about the effectiveness of problem-based ESP methods since they simulate possible professional situations and promote communication between future air traffic controllers and pilots, thus contributing to the acquisition of professional knowledge and activation of use of standard phraseology of radio exchange and plain English in non-routine situations. As shown by the results of our study, problem-based ESP methods are effective in raising future air traffic controllers' motivation to acquire Aviation English as they bring the learning closer to professional life.
\end{abstract}

Keywords: problem-based ESP methods; air traffic controllers; Aviation English; plain English; standard phraseology; radio exchange; non-routine situations; professional readiness.

\section{Introduction}

Researches assessing factors associated with accidents and incidents in aviation claim that over twothird of accidents are attributed to the human factor (Shappell, 2017). Among other problems identified in accident investigations such as inadequate leadership, inappropriate distribution of tasks, poor workload management etc., the problem of ineffective communication between crew members is considered one of the most serious, as air traffic controller-pilot communication takes place in a constrained but dynamic environment. It is usually highly scripted, brief, routine and, in most cases, unfolded as expected. In order to increase flight safety International Civil Aviation Organization (ICAO) (International Civil Aviation Organization, 2004) initiated implementation of new language proficiency requirements for air traffic controllers and pilots of non-English speaking countries which was followed by a number of theoretical and practical measures to improve Aviation English teaching process. Since the success of teaching ESP largely depends on appropriately chosen methods (Whyte \& Sarré, 2017), the objective of our study is to experimentally verify the efficiency of use of problem-based methods in the process of teaching future air traffic controllers to conduct radio exchange in non-routine situations.

\section{Theoretical framework}

Nowadays the development of aviation industry in Ukraine is directed towards its integration to international aviation network, training of competitive airmen at aviation educational institutions. Among others, there are important skills and knowledge necessary for competitive aviation specialists such as oral and written communicative skills, analytical thinking, problem-solving, decision-making, teamwork skills (Pazyura, 2016). Because air traffic controller-pilot communication is high-stakes interaction, miscommunication must be avoided so as to minimise the probability of an incident or accident occurring (Estival, 2016). Achievement of this goal, as seen by many scholars, is impossible without studying and applying new pedagogical approaches, teaching and learning methods for professional training of future aviation specialists. With this in mind, we find ESP methods the most appropriate for organising the educational process in an effective way with consideration of the students' motivation for their future professional activities, interests, skills and abilities. As stated by Dmytrenko (2003), ESP teaching is "the use of content, methods, forms and means of training that are consistent with the goals of education and the professional qualities of future specialists" (p. 26). The analysis of literature shows that all efforts in ESP teaching are directed to form specific purpose language ability which is perceived as a professional macro-

Bystrova, B., Nemlii, L., Pazyura N., \& Vasiukovych, O. (2019). Problem-based ESP methods for teaching future air traffic controllers to conduct radio exchange in non-routine situations. Advanced Education, 12, 74-79. DOI: 10.20535/2410-8286.155041 
skill comprising knowledge and competencies related to disciplinary, academic, or professional domains, and to particular modes of communication and relationships typical of each (Schug \& Le Cor, 2017).

According to Petko (2015), the formation of ESP learning environment at university is based on educational standards and normative documents of a particular speciality aimed at providing the future specialist with knowledge, skills and abilities necessary for employment and work in an industry in the modern period of information civilization. Researchers highlight the efficiency of gaming, interactive, information and communication technologies, collaborative learning, problem-based learning, portfolios (Wang \& Zhou, 2016). Ukrainian scientists (Timchenko \& Zelenska, 2017, p. 159) single out business games, role-plays, case studies, simulations, discussions, group discussions, modelling of professional communication as effective methods and techniques of simulation of the specific conditions of future aviation specialists' activity during the study of professional English. They are closely related and viewed as methods of problem-based learning (PBL) since they are similarly focused - on solving a real-world problem and, as stated by Moskalenko (2016, p.181) and Kovtun (2017, p.100), enhance the stable motivation of students for professional activity.

At present, an important task of training the aviation personnel in Ukraine is compliance to objectives and standards of ICAO which are generally accepted on international aviation routes (Petrashchuk, 2014). In accordance with the ICAO guidelines for aviation English training programmes, the emphasis is put on the communicative approach to language learning with the objective to improve speaking, listening and interactive skills. The radiotelephony communication is conducted during all flight stages and it normally uses standard radiotelephony English phraseology. In non-routine situations (e.g., distress calls) special phraseology is used. However, quite often this phraseology is not sufficient to achieve the communication intention, which can be caused by many reasons. Due to emergency or urgency especially under stress, the communicators may require much more language to interact in a cooperative manner. In view of this ICAO new English language requirements suggest the usage of plain English in radiotelephony communication. This suggestion is extremely important and must be realised in ESP programmes for air traffic controllers and flight crew members (Petrashchuk \& Vasiukovych, 2015, p.112). Therefore, future air traffic controllers are trained to manage interaction by switching off/on between standard phraseology and plain English. While standard phraseology is prescribed and regulated, plain English is used spontaneously and may vary greatly from one person to another.

Specific character of controller-pilot communication urges the need for particular conditions for improving the quality of training. Educational process must be specially created in which necessary competencies are formed as components of air traffic controllers' professional competence by means of advanced training methods and techniques (Petrashchuk \& Vasiukovych, 2015). As stated by ICAO (International Civil Aviation Organization, 2004), the developers of training materials for pilots and air traffic controllers should take into account students' general interests and motivation to learn the language. Thus, the scientific and methodological support, which requires the development and use of various pedagogically justified forms, tools, methods of creating the information environment accessible to each future air traffic controller, becomes the factor of his/her development, creates equal opportunities in mastering the profession for all learners.

\section{Methods}

This study was conducted at National Aviation University (Kyiv, Ukraine) during 2017-2018 academic year and involved 67 students studying for a bachelor's degree and majoring in "Aviation transport". The participants were divided into control and experimental groups matched by English language proficiency level. The students of the control group were taught ESP using traditional teaching methods. Their learning programme did not imply the use of a problem-based approach and the combination of plain English and standard phraseology during the English language radio exchange in non-routine situations. In the experimental group, we used problem-based learning (role-playing, simulation of specific situations, problem-solving, case studies). Role-playing was aimed at practising the phraseology of radio exchange between the air traffic controller and the pilot in non-routine situations. The students were asked to role play interviews between an air traffic controller and a journalist, or between an air traffic controller and a pilot etc. We organised pair-work and group-work training using professionally oriented role plays to help future air traffic controllers solve non-routine problems in flight. Students were encouraged to practice plain English in aviation context with the help of simulation of specific situations (for example, "Pressurisation problems", "Bird strike", "Emergency landings", "Fuel problems - critical fuel status", "Smoke or fire in the cockpit"). The teaching materials were presented to students in various formats: texts, videos, audio recordings. Special emphasis was made on the use of authentic, professionally focused video and audio 
materials for the practice of pronunciation which plays a key role in the safety of flights. This helped students learn about different accents, differentiate intonation, recognise paralinguistic features in nonroutine situations. In case studies every case was supplied with minimal necessary information using which the students were able to develop a discussion and offer their view on the possible solution.

We defined insufficient and sufficient levels of the professional readiness of future air traffic controllers to conduct radio exchange in non-routine situations. The criteria for defining the levels of professional readiness were: cognitive (knowledge of terminological clichés of radio-communication, non-routine situations and appropriate actions of air traffic controllers, standard phraseology and plain English used in professional context), functional, or operational (listening skills, decision-making skills in non-routine situations, skills to conduct radio communication, ability to apply plain English and standard phraseology in practical context) and students' motivation to study Aviation English. In order to define these levels, we used a mixed methods approach which included testing, class observations and questionnaires. Reliability of the received experimental data was verified by methods of mathematical statistics with the use of the t-criterion of Student.

Testing was conducted in the control and experimental groups at the beginning and the end of the academic year. It was aimed at defining the levels of cognitive and functional (operational) readiness of future air traffic controllers and contained tasks for classification of non-routine situations in flight, determination of key elements of distress and emergency messages, checking the students' knowledge of ICAO documents, standard phraseology, vocabulary for non-standard radio exchange. The tests included problem-solving tasks based on non-routine situations in flight - pressurisation problems, bird strike cases, emergency landings, critical fuel status problems, smoke or fire in the cockpit emergencies. The testing of communicative skills necessary for linguistic interaction in pilot-air traffic controller communication involved: conducting language acts directed at inducing to an action (instructions, inquiries, advice / consultations, etc.); exchange of information (about the current situation, about past and future actions / events, urgent needs, tasks, available opportunities, etc.); managing pilot-air traffic controller interactions (greetings / farewells, expression of satisfaction / dissatisfaction / anxiety, etc.); dialogue management (a request for an answer, verification and accuracy of understanding, elimination of misunderstanding, etc.).

Class observations were conducted by the authors during the course of Aviation English to evaluate the students' motivation by their engagement in class activities. Behaviours were classified into three types: disengagement, passive engagement and active oral or written participation.

Questionnaires were offered to the students of the experimental group at the end of the academic year. In them, the students had to comment on whether they liked using problem-based learning in ESP classes, the emotions they felt during lessons of Aviation English, whether their motivation changed while taking the course and whether such learning was meaningful for them. The questionnaire also had an open-ended question about the activity they considered the most useful.

\section{Results}

The results of the testing at the beginning of the academic year showed nearly the same level of readiness in the control and experimental groups. The tests were assessed using the ECTS grading scale (from A to E) which splits into five segments: A - 100-90; B - 89-82; C - 81-75; D - 74-67; E - 66-60. According to the results, before the learning experiment, $32.35 \%$ of students of the experimental group had A-marks. After the experiment, the percentage of the students with A marks increased to $73.53 \%$. The difference reached $41.18 \%$. The percentage of students with B marks equalled $38.24 \%$ before and $23.53 \%$ after the learning experiment, the decrease constituting $14.71 \%$. Similarly, the percentage of students of the experimental group with $\mathrm{C}$ marks which indicated an insufficient level of professional readiness decreased from $29.41 \%$ to $2.94 \%$, with a difference of $26.47 \%$. In the control group, the differences in the levels of students' readiness before and after the experiment were not so significant. The sufficient level after the experiment was revealed in $42.42 \%$ (vs. $30.31 \%$ before the experiment). There was also a less significant (in comparison with the experimental group $-15.14 \%$ vs. $26.47 \%$ ) decrease in the number of students with an insufficient level of professional readiness after the experiment. The results of the testing are summarised in Table 1.

The analysis of the data obtained during the observations shows that the level of students' motivation in the experimental group was higher than in the control group due to the use of problem-based methods. Fewer instances of disengagement were observed in this group during group or class discussions. The rate of engagement was assessed as high in the experimental group with an overwhelming majority of students engaged in problem-based activities. At the same time, only a little more than half of the students took interest in learning in the control group where passive engagement was more predominant. 
Table 1. Results of the testing of future air traffic controllers before and after the training experiment

\begin{tabular}{|c|c|c|c|c|c|c|c|c|c|c|}
\hline \multirow{3}{*}{ Marks } & \multicolumn{5}{|c|}{ Control group } & \multicolumn{5}{|c|}{ Experimental group } \\
\hline & \multicolumn{2}{|c|}{$\begin{array}{c}\text { Before } \\
\text { the training } \\
\text { experiment }\end{array}$} & \multicolumn{2}{|c|}{$\begin{array}{l}\text { After } \\
\text { the training } \\
\text { experiment }\end{array}$} & \multirow{2}{*}{$\begin{array}{c}\text { Difference } \\
\\
\%\end{array}$} & \multicolumn{2}{|c|}{$\begin{array}{l}\text { Before } \\
\text { the training } \\
\text { experiment }\end{array}$} & \multicolumn{2}{|c|}{$\begin{array}{l}\text { After } \\
\text { the training } \\
\text { experiment }\end{array}$} & \multirow{2}{*}{$\begin{array}{c}\text { Difference } \\
\\
\%\end{array}$} \\
\hline & Students & $\%$ & students & $\%$ & & students & $\%$ & students & $\%$ & \\
\hline A & 10 & 30.31 & 14 & 42.42 & +12.11 & 11 & 32.35 & 25 & 73.53 & +41.18 \\
\hline $\mathrm{B}$ & 15 & 45.45 & 16 & 48.48 & +3.03 & 13 & 38.24 & 8 & 23.53 & -14.71 \\
\hline $\mathrm{C}$ & 8 & 24.24 & 3 & 9.1 & -15.14 & 10 & 29.41 & 1 & 2.94 & -26.47 \\
\hline Total & 33 & 100 & 33 & 100 & & 34 & 100 & 34 & 100 & \\
\hline
\end{tabular}

The analysis of the questionnaire answers showed that the majority $(72.6 \%)$ of students in the experimental group were excited to attend Aviation English classes because they found the tasks and activities interesting. Most students in this group $(94.1 \%)$ considered their classes useful, practically focused, improving their skills and knowledge. When answering the open-ended question about the activity they considered the most useful, the majority of students chose problem-solving tasks and listening to authentic radiotelephony communication between pilots and air-traffic controllers in non-standard situations with further discussions ( $87.3 \%$ and $89.7 \%$, respectively).

Thus, the positive dynamics of learning results in the experimental group proved the effectiveness of problem-based ESP methods in comparison with traditional methods for training future air traffic controllers to conduct radio exchange in non-routine situations.

\section{Discussion}

With strong intention to comply with ICAO requirements we used ESP communicative problem-based activities (role-playing, simulation of specific situations, problem-solving, case studies) to develop the professional readiness of future air traffic controllers to conduct radio exchange in non-routine situations. The results of our research contribute to the understanding of what such professional readiness is and how problem-based ESP methods can facilitate its development. Our findings are in line with a number of authors' studies devoted to problem-based ESP methods tailored to certain professional activities (Gai, 2017; Chung-chien Chang, 2017; Hutchinson \& Waters, 1987; Karimnia \& Khosravani, 2018) as well as standards of ICAO (International Civil Aviation Organization, 2004; International Civil Aviation Organization, 2009). In the context of our research, we consider communicative skills to be an integral part of professional readiness of future air traffic controllers to conduct radio exchange in non-routine situations, the other components being cognitive and functional ones together with motivation to study professionally focused language. In this regard, it is important to emphasise that ESP communicative problem-based activities promote the development of communication skills together with the development of cognitive and functional (operational) components of readiness to conduct radio exchange.

The choice of problem-based methods used in the course of Aviation English finds strong theoretical and empirical support from the field of ESP research. Thus, previous researches show that problem-based methods of language teaching in ESP classrooms help learners improve their proficiency more successfully as they possess much knowledge of the subject matter they study. This knowledge is critical for the success as it enables them to solve profession-related problems (Karimnia \& Khosravani, 2018, p. 159). We totally agree that communicative approach enables teachers to design training on the basis of real life communication and enhance appropriate motivation due to the immersion of students in simulated air traffic activities. Such communication gives learners opportunities not only to implicitly and subconsciously develop their English professional communication skills but also to acquire professional knowledge and skills in the process of communication necessary to conduct radio exchange. Professional intercourse in professional situations (even modelled) is always connected with problem-solving. This makes the ESP teaching/learning process problem-based (Tarnopolsky, 2015).

Based on the results of our research we totally agree with Koutsides (2009) who emphasises that work in small groups promotes cooperative learning, creates possibilities for discussion of problems, enhances the learning outcomes due to students' active involvement. Analysing the ICAO international documents, we focused on the list of events that are related to non-routine situations in the process of air traffic control and possible actions of future air traffic controllers, for example: landing delays, radio communication failure, adverse meteorological conditions, unlawful interference, fire on board, pilot's incapacitation, etc. Interactive tasks connected with such non-routine situations encouraged students to talk, offer their solutions, 
share information about the cases, be engaged in searches of professional information, which is particularly important in ESP learning. Role-playing between the air traffic controller and the pilot in non-routine situations helped to enlarge English aviation vocabulary. Also, the simulation of airmen performance at their job place in non-routine situations developed fluency in plain English in aviation context. In our opinion, the above-mentioned learning methods promote the development of students' interpersonal communicative skills as also their learning, teamwork, interaction, time management, problem-solving skills.

We would also like to point out that as practitioners we have many options in selecting materials suitable for ESP courses. We strongly support Medrea and Rus's (2012) opinion that using a single coursebook cannot provide comprehensive training. We think that Aviation English textbooks might be too general when we aim to teach future air traffic controllers to conduct radio exchange in non-routine situations. Understanding the needs and expectations of our learners should be a key concern in selecting appropriate materials. We believe that the right choice of materials allows us to achieve a significant degree of customisation of Aviation English to the future air traffic controllers' needs. Particularly effective, in our opinion, are videos and problem-based tasks created on their basis. It is important that videos should provide a diversity of accents of Great Britain, the USA and other English-speaking countries. By designing professionally oriented video materials, prepared specifically for future air traffic controllers, we tried to present aviation profession environments and contexts.

In our study we attributed much attention to motivation which is a key factor of the development of professional readiness to conduct radio exchange in non-routine situations and, as defined by Schug and Le Cor (2017), is a dynamic phenomenon, strongly dependent on all the factors present in a given system (in our case - a language classroom). The analysis of the questionnaires and observation data which were used to explore students' motivation in acquiring knowledge and skills necessary to conduct radio exchange in nonroutine situations indicated that future air traffic controllers' motivation was basically dependent on the communicative nature of learning activities.

It is necessary to point out that in our research we evaluated the effectiveness of problem-based learning methods only, while there are other communicative ESP methods which, in our opinion, can be successfully used in teaching future air traffic controllers and thus may be a subject of further study.

\section{Conclusions}

The results of our experiment allow us to make a conclusion that the success of the development of the professional readiness of future air traffic controllers to conduct radio exchange in non-routine situations depends to a large extent on the content and methods of learning. Implementation of the ICAO objectives and standards regarding communicative competence and readiness of future air traffic controllers to conduct radio exchange is possible through the use of problem-based ESP methods, particularly, role-playing, simulation of specific situations, problem-solving, case studies, since they simulate possible professional situations and promote communication between future air traffic controllers and pilots, thus contributing to the acquisition of professional knowledge and activating the use of standard phraseology of radio exchange and plain English in non-routine situations. As shown by the results of our study, problem-based ESP methods are effective in raising future air traffic controllers' motivation to acquire Aviation English as they bring the learning closer to professional life.

\section{References:}

Chung-chien Chang, K. (2017). From EAP to ESP: a teacher's identity development. Taiwan Journal of TESOL, 14 (2), 71-100. Retrieved 5 January 2019 from https://eric.ed.gov/?id=EJ1171158

Dmytrenko, T. (2003). Novyie obrazovatelnyie tehnologii v vyisshey pedagogicheskoy shkole [New educational technologies in higher pedagogical school]. Vyisshee obrazovanie segodnya, 8, 26-31.

Estival, D., Farris, C., \& Molesworth, B. (2016). Aviation English. London: Routledge. https://doi.org/10.4324/9781315661179

Gai, F. (2017). Construction of ESP teaching system. Journal of Language Teaching and Research, 8 (6), 1204-1209. https://doi.org/10.17507/jltr.0806.23

Hoekje, B. (2012). Teaching English for medical and health professionals. In C. Chapelle (Ed.), The encyclopedia of applied linguistics. Oxford: Blackwell. https://doi. org/10.1002/9781405198431.wbeal1154

Hutchinson, T., \& Waters, A. (1987). English for specific purposes: A learning-centered approach. Cambridge University Press https://doi.org/ 10.1017/CBO9780511733031

International Civil Aviation Organization. (2009). Guidelines for aviation English training programs (Cir 323. AN/185). Montréal: ICAO.

International Civil Aviation Organization. (2004). Manual on the implementation of ICAO language proficiency requirements (Cir 9835. AN/453). Montréal: ICAO.

Karimnia, A. \& Khosravani, M. (2018). A comparative study of form-focused and communicative methods of language teaching in ESP courses. Sustainable Multilingualism, 12 (1), 152-165. https://doi.org/10.2478/sm-2018-0007

Kovtun, O. (2017). Aktyvni metody profesiino-movlennievoi pidhotovky maibutnikh fakhivtsiv u systemi inzhenerno-tekhnichnoi osvity [Active methods of vocational training of future specialists in the system of engineering and technical education]. In 
Vyscha shkola: Udoskonalennia yakosti pidhotovky fakhivtsiv: Materialy I Mizhnarodnoi. naukovo-praktychnoyi internetkonferentsii (pp. 98-101). Kyiv, Ukraine: NAU.

Koutsides, G. (2009). Using cooperative learning in design and technology. The Journal of Design and Technology Education, 6 (1), 55-59. Retrieved 16 December 2017 from: https://ojs.lboro.ac.uk/JDTE/article/view/437

Medrea, N., \& Rus, D. (2012). Challenges in teaching ESP: Teaching resources and students' needs. Procedia Economics and Finance, 3, 1165-1169. https://doi:10.1016/s2212-5671(12)00291-2

Moskalenko, O. (2016). Pedahohichni umovy navchannya profesiynoyi anhlomovnoyi komunikatsiyi maybutnikh aviatsiynykh fakhivtsiv [Pedagogical conditions for professional English-language communication training of future aviation specialists]. Pedahohichni nauky: Teoriya, istoriya, innovatsiyni tekhnolohiyi, 8 (62), 178-187. Retrieved 25 December, 2018 from https://pedscience.sspu.sumy.ua/?page_id=1326

Pazyura, N. (2016). Main aspects in language training of non-English speaking airmen. Proceedings of the National Aviation University, 69 (4). https://doi.org/10.18372/2306-1472.69.11063

Petraschuk, O. (2014). Integrated approach to language training of air traffic controllers. Proceedings of the National Aviation University, 58 (1), 84-89. https://doi.org/10.18372/2306-1472.58.6699

Petraschuk, O., \& Vasiukovych, O. (2015). Rationale for linguistic profile of aviation English language training course. Proceedings of the National Aviation University, 63 (2), 112-120. https://doi.org/10.18372/2306-1472.63.8878

Petko, L. (2015). Profesiyno oriyentovani tekhnolohiyi navchannya yak zasib formuvannya profesiyno oriyentovanoho inshomovnoho navchalnoho seredovyscha $\mathrm{v}$ umovakh universytetu [Professionally oriented learning technologies as a method of forming a professionally oriented foreign language learning environment in higher education institutions]. Mizhnarodnyy naukovyy forum: Sotsiolohiya, psykholohiya, pedahohika, menedzhment, 18, 175-184.

Schug, D. \& Le Cor, G. (2017). Towards a dynamic approach to analysing student motivation in ESP courses. In C. Sarré \& S. Whyte (Eds.), New developments in ESP teaching and learning research (pp. 73-91). https://doi.org/10.14705/rpnet.2017.cssw2017.746

Shappell, S., Detwiler, C., Holcomb, K., Hackworth, C., Boquet, A., \& Wiegmann, D. A. (2007). Human error and commercial aviation accidents: An analysis using the human factors analysis and classification system. Human Factors, 49 (2), $227-$ 242. https://doi.org/10.1518/001872007X312469

Tarnopolsky, O. (2015). Idea sharing: Professionalizing ESP teaching to university students through modeling professional interaction in ESP classrooms. PASAA, 50, 155-172. Retrieved 15 January 2019 from https://files.eric.ed.gov/fulltext/EJ1088303.pdf

Tymchenko, S. \& Zelens`ka, L. (2017). Aktyvne navchannya u formuvanni profesiynoho spilkuvannya maybutnikh aviafakhivtsiv u protsesi vyvchennya profesiynoyi anhliys'koyi movy [Active training in formation of professional communication of future aviation specialists in the process of studying professional English language]. Visnyk Zhytomyrs'koho derzhavnoho universytetu imeni Ivana Franka, 1 (87), 158-162. Retrieved 15 January 2019 from https://visnyk.zu.edu.ua/Articles.php

Wang, W. \& Zhou, C. (2016). Effective strategies to improve English teaching. Information Science and Management Engineering, IV (1), 217-220. https://doi.org/10.5220/0006447502170220

Whyte, S., \& Sarré, C. (2017). Introduction to new developments in ESP teaching and learning research. In C. Sarré \& S. Whyte (Eds.), New developments in ESP teaching and learning research (pp. 1-12). https://doi.org/10.14705/rpnet.2017.cssw2017.742 